\title{
PERAN MODAL SOSIAL DALAM IMPLEMENTASI KONSEP PEMIKIRAN KI HADJAR DEWANTARA DI SD TAMAN MUDA YOGYAKARTA
}

\author{
Sukma Wijayanto \\ Program Studi Pendidikan Dasar Program Pascasarjana Universitas Negeri Yogyakarta \\ sukmawijayantoind@google.com
}

\begin{abstract}
Abstrak
Penelitian ini bertujuan untuk mendeskripsikan: (1) implementasi pendidikan Ki Hadjar Dewantara; dan (2) modal sosial di SD Taman Siswa Jetis. Penelitian menggunakan pendekatan kualitatif dengan jenis penelitian studi kasus. Unit analisis penelitian adalah SD Tamansiswa Jetis. Penentuan subjek dalam penelitian ini menggunakan teknik purposive sampling dengan subjek penelitian adalah pamong, kepala sekolahdan ketua yayasan Majelis Luhur Persatuan Tamansiswa cabang Jetis. Teknik pengumpulan data menggunakan observasi partisipatif, wawancara dan dokumentasi. Teknik analisis penelitian ini menggunakan model interaktif Milles \& Huberman. Berdasarkan penelitian diperoleh sebagai berikut: (1) Konsep pemikiran Ki Hadjar terlaksana di SD Taman Siswa Jetis yakni sistem among tidak dapat dipisahkan prinsip kemerdekaan dan kodrat alam. Pelaksanaan sistem among dilaksanakan dengan keteladanan, pembiasaan, pengajaran, serta hukumam, paksaan dan perintah. (2) Trust, Jaringan, dan norm dalam melaksanakan konsep Ki Hadjar Dewantara menggunakan nilai-nilai kekeluargaan. Kekeluargaan modal sosial yang menjadi kekuatan dalam melaksanakan konsep pendidikan Ki Hadjar di SD Taman Siswa Jetis.
\end{abstract}

Kata kunci: Ki Hadjar Dewantara, Konsep Pendidikan Ki Hadjar Dewantara, Modal Sosial

\section{THE ROLE OF SOCIAL CAPITAL IN THE IMPLEMENTATION OF KI HADJAR DEWANTARA'S CONCEPT OF EDUCATION IN SD TAMAN MUDA YOGYAKARTA}

\author{
Sukma Wijayanto \\ Program Studi Pendidikan Dasar Program Pascasarjana Universitas Negeri Yogyakarta \\ sukmawijayantoind@google.com
}

\begin{abstract}
This study aims to describe: (1) the implementation of Ki Hadjar Dewantara's education (2) the social capital in SD Tamansiswa Jetis. This study belonged to qualitative study and use case study as its type of study. The sample was SD Tamansiswa Jetis and it was selected using purposive sampling technique. The research participants were anofficer, headmaster and chairman of Persatuan Majelis Luhur Tamansiswa Djetis. Data collecting techniques used in this study were participative observation, interviewand documentation. While, the analysis technique of this study was interactive model of Milles and Huberman. Based on this study, it is obtained that: (1) Ki Hadjar Dewantara's concepts about the objectives have been implemented in SD Tamansiswa, Jetis. Among system is implemented with the freedom principle and nature. The implementation of among system is done with modelling, habituating, teaching, punishing, forcing and commanding. (2) Trust, network and norm in implementing the concept of Ki Hadjar Dewantara use kinship value. Kinship is the social capital that becomes the power in implementing Ki Hadjar'sconcept of education in SD Tamansiswa Jetis
\end{abstract}

Keywords: Ki Hadjar Dewantara, Ki Hadjar Dewantara's Concept of Education, Social Capital 


\section{PENDAHULUAN}

Pendidikan nasional Indonesia diupayakan dalam rangka menghadapi tantangan di era globalisasi tersebut. Pendidikan yang dirancang secara nasional memuat konsep yang mengembangkan tiga aspek dalam diri siswa, yang tidak terpaku pada kognitif siswa saja, namun anak perlu dikembangkan segala potensi kodratinya untuk menjadi manusia yang seutuhnya.

Kegiatan mendidik tidak hanya dilakukan untuk tujuan minterke, namun potensi dan budi pekerti anak harus juga dikembangkan. Pendidikan bertanggung jawab membentuk manusia manusia seutuhnya yang mencakup aspek kognitif, spiritual, dan aspek sosial. Pendidikan harus diupayakan dengan sebaik-baiknya untuk kebahagiaan anak itu sendiri dan lebih jauh lagi guna membangun bangsa dan negara yang menjadi harapan semua orang.

Membicarakan pendidikan di Indonesia nama Ki Hadjar Dewantara tidak dapat dilupakan. Ki Hadjar Dewantara sebagai tokoh pendidikan nasional mempunyai andil besar dalam membangun manusia melalui pendidikan. Konsep pendidikan yang diwariskan tidak hanya mementingkan kecerdasan dan intelektualitas. Dewantara (2011, p. 485) mengungkapkan bahwa pendidikan merupakan penyokong perkembangan hidup anakanak lahir dan batin, dari sifat kodratnya menuju ke arah peradaban dalam sifatnya yang umum.

Ki Hadjar Dewantara memberikan gambaran bahwa pendidikan haruslah membantu siswa menuju kearah manusia beradab yang ditandai dengan penguasaan pengetahuan, akhlak dan dapat mencapai kembahagiaan yang sebenarnya. Dewantara (2011, pp. 14 15) menjelaskan secara panjang lebar mengenai definisi pendidikan. Ki Hadjar Dewantara mengatakan bahwa pendidikan secara umum merupakan daya upaya memajukan tumbuhnya budi pekerti (kekuatan batin dan karakter), pikiran (intelektual), dan tubuh anak agar dapat mencapai kesempurnaan hidup, yakni kehidupan yang selaras dengan dunianya.

Keterampilan dan penguasaan kehidupan sosial. Pendidikan diupayakan dalam tujuan membentuk manusia yang sesungguhnya, bukan bagian tertentu dari manusia yang ditonjolkan seperti yang terjadi dalam proses pendidikan sekarang yang mengutamakan kognitif dan intelektualitas.

Pemikiran dan konsep Ki Hadjar Dewantara bisa dikatakan sangat brilian pada zaman tersebut.Diantara konsep tersebut adalah mengenai kemerdekaan berfikir dan mendidik siswa berdasarkan kodratnya sebagai alam itu sendiri dan bagian dari alam (Yamin, 2009, p. 174). Konsep pendidikan Ki Hadjar Dewantara yang memasukkan ide pancasila perlu di populerka dan diterapkan kembali untuk mndapatkan identitas pendidikan Indonesia yang berbudaya.

Tamansiswa merupakan yayasan yang didirikan dari oleh Ki Hadjar Dewantara sebagai implementasi atas pemikiran-pemikirannya dalam pendidikan. Tamansiswa didirikan dengan tujuan yang sangat mulia sebagai untuk bangsa, mendukung pergerakan nasional, dan menanamkan "benih-benih" berkualitas pada siswa sehingga menjadi pribadi yang kuat di kehidupannya kelak (Dewantara, 2011, p. 13). Pendidikan di Tamansiswa memberikan bekal bagi kehidupan siswa untuk tujuan lahir dan batin siswa.Tujuan lahir yaitu, memberikan bekal pengetahuan, sosial, fisik, dan keterampilan. Tujuan batin ialah berdasarkan prinsip budaya (Dewantara, 2011, p. 115). Di sinilah pemikiran Ki Hadjar Dewantara diimplementasikan dalam pendidikan Tamansiswa.

Pendidikan tidak hanya dibebankan pada sekolah. Lingkungan keluarga dan lingkungan anak tempat dia berada ikut ambil bagian dalam pencapaian tujuan pendidikan.

Konsep pendidikan Ki Hadjar Dewantara menghendaki agar sekolah, orang tua danlingkungan anak menjadi tempat berlangsungnya pendidikan. Pusat pendidikan tersebutharus berjalan dengan baik dan saling mendukung demi tercapainya pendidikan bagi siswa. Kerja sama dengan berbagai perlu dioptimalkan sebagai modal sosial untuk mencapai tujuan pendidikan. Program pendidikan yang melibatkan berbagai pihak diantaranya orang tua dan masyarakat perlu dicanangkan dan dilaksanakan para stekholder dalam meningkatkan kualitas (Tobias, Wales, Syamsulhakim, \& Suharti, 2013, p. 7).

Tamansiswa sebagai yayasan yang didirikan oleh Ki Hadjar Dewantara memiliki konsep-konsep yang merupakan pemikiran $\mathrm{Ki}$ Hadjar Dewantara dalam pendidikan (Dewantara, 2011, p. 64). Tujuan pendidikan Ki Hadjar Dewantara secara khusus diungkapkan 
oleh Wuryadi (2010, p. 21) bahwa pendidikan dalam konsep Ki Hadjar Dewantara juga merupakan usaha menuju masyarakat yang berbudaya, bisa dikatakan pula bahwa dengan salah satu perjuangan kebudayaan adalah melalui pendidikan. Tujuan pendidikan $\mathrm{Ki}$ Hadjar Dewantara merupakan tujuan pendidikan yang selaras dengan pendidikan nasional.Ki Hadjar Dewantara (2011 p.95) mengatakan bahwa pendidikan bertujuan memelihara kecerdasan akal budi untuk segenap rakyat.

SD Tamanmuda Jetis merupakan sekolah yang berada di naungan yayasan majelis luhur Tamansiswa. SD Tamanmuda memiliki kelebihan dan keunggulan, disamping kelebihannya dengan konsep pendidikan $\mathrm{Ki}$ Hadjar Dewantara yang diterapakan. Salah satu keunikan dan kelebihan di SD Taman Muda Jetis berada di kampong ramah anak. Lokasi ramah anak tersebut menjadi tempat yang diprogrampakan oleh pemerintah kota Yogyakarta. Keunggulan mengenai penerapan ajaran luhur dari budaya juga menjadi keunikan tersendiri di tengah arus moderniasi. Sekolah yang berada di eilayah Cokrowijayan, Kranggan ini juga memiliki kerja sama dan jaringan yang baik dalam yayasan Tamansiswa cabang Jetis dalam membangun dan mengembangkan konsep Ki Hadjar Dewanata. Hal itu menadi modal sosial yang ada dalam suatu lembaga sebagai sarana membangun hubungan dalam meningkatkan kualitas pendidikan tingkat satuan.

Kepercayaan dan jaringan antaranggota menjadi kekuatan dalam menuai hasil dari proses pendidikan. Saling percaya antarindividu dalam kelembagaan, jaringan yang dimiliki, serta norma yang dihormati menjadi modal sosial dalam instansi yang bersangkut-an. Pernyataan tersebut menjelaskan pada bahwa jaringan sosial dan norma memiliki pe-ranan dalam mengembangkan pembelajaran. Lebih lanjut, Field (2005, p. 35) Memaparkan bahwa, "Social capital, then can promote learning. Yet learning is not solely a simple by-product of social conections. People also bring their existing skills and knowledge to their connections". Modal sosial sebagai daya penghubung aktif berada dalam anggota suatu komunitas atau kelompok meliputi rasa saling percaya saling pengertian angata anggota yang diikat oleh aturan, serta terikat dalam sebuah jaringan kelompok atau komunitas dan senantiasa memungkinkan adanya kerja sama untuk mencapai tujuan.

Modal sosial yang kuat memper-mudah pencapain tujuan pendidikan di sekolah. Hal tersebut seperti yang dikatakan Aslandogan and Cetin (Acar, 2011, p. 458) "improvement of social capital in an educational context refers to the establishment of tripartite educator-parent-sponsorship (community) relationships and networking. Modal sosial dalam suatu tingkat satuan pendidikan memiliki berbagai unsur. Diantara berbagai unsur tersebut adalah kerja sama antara pamong, kerja sama pamong dengan orang tua siswa dan kerja sama dengan, masyarakat.

Secara sederhana, modal sosial merupakan konsep yang memuat mengenai hubungan sosial. Coleman (Häuberer, 2011, p. 53) memperkenalkan modal sosial sebagai sarana konseptual untuk memahami orientasi teoritis tindakan sosial. Modal sosial (social capital) berperan dalam menciptakan sumber daya manusia (human capital) dengan cara memperlihatkan apa yang berlangsung dalam keluarga dan masyarakat dalam proses perkembangan pendidikan anak-anak. Modal sosial adalah sesuatu yang penting dalam sebuah hubungan instasi untuk membentuk ikatan antarindividu yang membentuk jaringan sosial, norma, serta hubungan timbal balik dalam interaksi antarindividu tersebut sehinga tujuan institusi dapat lebih mudah tercapai (Häuberer, 2011, p. 53).

Modal sosial memuat berbagai unsur pembentuk diantaranya adalah trust (rasa saling percarya). Badaruddin (Darmayanti \& Wibowo, 2014, p. 140) mengungkapkan, sikap saling percaya (trust) meliputi adanya unsur kejujuran (honesty), kewajaran (fainerss), sikap egaliter (egali-tarianism), toleransi (tolerance) dan kemurahan hati (generosity). Sebuah institusi akan berkembang dengan didasari oleh rasa saling percaya. Coleman, (1988, p. 103) mengatakan without high degree of trustwortness among the members of the group, the institution caould not exist. Rasa saling percaya tersebut menjadi bangunan dasar dalam berinteraksi dalam institusi dan kelembagaan.

Disamping trust, terdapat pula jaringan (network). Jaringan membentuk ikatan antarindividu sepertihanya tali yang saling terkait membentuk pukat yang digunakan 
nelayan. Network dapat ditunjukkan dengan adanya ikatan dalam anggota yang dilakukan sebagi kekuatan yang dapat diakses dalam kondisi yang mengikat dalam hubungan sosial.

Disiamping trust dan jaringan terdapat pula norma. Norma atau pranata berfungsi sebagai landasan yang mengikat hubungan antarmanusia dalam kelompok. Francis Fukuyama (Wibowo, 2007, p. 20) menekankan bawa norma berguna pada dimensi yang lebih luas yaitu segala sesuatu yang membuat masyarakat bersekutu untuk mencapai tujuan bersama atas dasar kebersamaan dan di dalamnya didiikat oleh nilai-nilai dan norma yang tumbuh dan dipatuhi. Ketiga unsur tersebut menjadi tersebut merupakan modal dasar dalam membentuk kekuatan sosial sebagai suatu capital yang berguna dalam mencapai tujuan.

Unsur-unsur dalam modal sosial yaitu jaringan, kepercayaan, pranata, dan jaringan. Unsur ini jika terjalin dengan baik akan menghasilkan suatu kekuatan dalam sebuah hubungan, meningkatnya kinerja, dan berkembangnya suatu organisasi termasuk dalam pendidikan. Sumber terpenting dari social capital sistem pendidikan yang menjadi kekayaan publik di suatu negara (Yusuf, 2001, p. 22).

Penguatan modal sosial merupakan salah satu langkah dalam upaya menghadapi tantangan dalam mencapai tujuan kelembagaan sebagai suatu hasil dari interaksi dan jalinan erat antarindividu dalam institusi. Modal sosial sangat dibutuhkan dalam pendidikan, karena memuat mengenai norma, peraturan, kerja sama, kepercayaan, dan jaringan, yang semua itu berimbas pada kualitas pada institusi pendidikan yang bersangkutan.

Konsep pendidikan Ki Hadjar Dewantara masih sangat relevan untuk selalu diterapkan. Konsep pendidikan tersebut tidak hanya membentuk manusia yang ngerti, namun juga ngrasa, dan mampu nglakoni. Konsep Ki Hadjar Dewantara mengharapakan pendidikan yang tidak hanya memberikan bekal kepandaian, namun budi pekerti menjadi hal yang ditekankan dengan didasarkan pada nilai kebenaran mutlak yang trandsenden serta nilai keluhuran budi dari kebudayaan. Pelaksanaan konsep pendidikan tersebut membutuhkan modal sosial guna menjadi daya dan kekuatan untuk mencapai tujuan pendidikan yang diharapkan.

\section{METODE PENELITIAN}

Pendekatan penelitian ini menggunakan pendektan post-positivistik atau kualitatif. Penggunaan pendekatan kualitatif untuk mendapatkan data yang rinci, mendalam dan lengkap. Pendekatan kualitatif dilakukan secara natural tanpa ada campur tangan dari peneliti dalam objek penelitian. Jenis penelitian yang digunakan dalam penelitian ini adalah studi kasus. Studi kasus merupakan pendekatan kulitatif dengan penggalian informasi dalam suatu konteks dalam kasus atau fenomena tertentu.

Penelitian ini dilaksanakan di Sekolah Taman Muda Jetis Kabupaten Sleman Daerah Istimewa Yogyakarta. Sekolah Taman Muda merupakan lembaga pendidikan di bawah naungan Yayasan Majelis Luhur Tamansiswa yang berada dalam satu komplek dengan Taman Indria. Taman Muda Jetis dipilih sebagai tempat penelitian karena sekolah tersebut menggunakan konsep pendidikan $\mathrm{Ki}$ Hadjar Dewantara. Pra-penelitian dilakukan pada bulan Agustus-September 2015. Penelitian secara intensif dilakukan selama tiga bulan, yaitu pada bulan Februari 2016 sampai Mei 2016.

Unit analisis dalam penelitian ini adalah SD Taman Muda, Jetis. Penentuan subjek dalam penelitian ini menggunakan teknik purpose sampling. Purpose sampling adalah menentukan informan dengan pertimbangan tertentu yang dipandang dapat memberikan data secara mendetail. Informan dari penelitian ini adalah Ketua cabang yayasan Tamansiswa Jetis, kepala sekolah, guru, karyawan dan orang tua siswa Taman Muda Jetis.

Sumber primer pada penilitian ini adalah tulisan-tulisan dari Ki Hadjar Dewantara (studi literatur). Sedangkan sumber sekundernya adalah Ketua cabang yaysan Tamansiswa Jetis, 4 orang tua siswa dan warga SD Taman Muda Jetis yang mencakup kepala sekolah, 8pamong (guru), 1 karyawan serta10 siswa.

Instumen yang digunakan dalam penelitian ini pedoman wawancara, pedoman observasi dan catatatan lapangan. Keabsahan data didasarkan pada validitas. Validitas merupakan bentuk dan ketetapan instrumen yang 
dapat mengukur serta menilai instrumen apa yang ingin dinilai. Keabsahan data dalam metode penelitian kualitatif ini adalah uji validitas internal (credibility) yaitu triangulasi. Triangulasi meruapakan salah satu cara dalam melakukan kredibilitas dalam keabsahan data.

\section{HASIL PENELITIAN DAN PEMBAHASAN}

\section{Hasil}

Pendidikan Ki Hadjar Dewantara bertujuan untuk meningkatkan kemampuan akal dan menjadikan berbudi pekerti luhur. Sistem among merupakan merupakan sistem yang dibangun atas dasar memanusiakan manusia. Pendidikan Ki Hadjar Dewantara bertujuan untuk meningkatkan kemampuan akal dan menjadikan berbudi pekerti luhur. Tujuan pendididikan di SD Taman Muda merupakan tujuan pendidikan tingkat satuan yang diturunkan dari konsep pemikiran Ki Hadjar Dewantara. Berdasarkan paparan hasil penelitian, dapat ditarik kesimpulan bahwa beberapa tujuan pendidikan pamong adalah (a) Kedewasaan, (b) mencerdasakann siswa, (c) mengarahkan budi perkerti, karakter atau akhlak, (d) mengembangkat minat dan bakat siswa.

Tujuan pendidikan yang dijalankan pamong selaras dengan tujuan pendidikan dan visi misi sekolah yang dijabarkan dari tujuan pendidika Ki Hadjar Dewantara. Pamong memahami tujuan pendidikan Ki Hadjar Dewantara tidak secara keseluruhan, namun begitu tujuan tersebut tetap terealisasi dikarenakan pamong mengimplementasikan tujuan tersebut berdasarkan visi dan misi yang terprogram dalam kurikulum.

Sistem among merupakan merupakan sistem yang dibangun atas dasar memanusiakan manusia. Selaras dengan hal tersebut maka sistem among memuat prinsip dan cara dalam pelaksanannya Selaras dengan hal tersebut maka sistem among memuat prinsip dan cara dalam pelaksanannya. Pelaksanaan pada kegiatan pembelajaran, prinsip kemerdekaan telah dilaksanakan, meskipun terdapat pula hal yang belum memerdekakan siswa. Kegiatan yang mengandung unsur paksaan dan perintah dilaksanakan di SD Taman Muda Jetis.

Pencapaian target kognitif siswa yang dilakukan di sekolah menjadi kendala dalam memerdekakan siswa. Target kognitif yang berorintasi pada nilai hasil belajar siswa secara sistemik terpengaruh karena hasil yang didapatkan siswa menjadi tolak ukur keberhasil siswa, dan tentunya menjadi salah satu indikator kerberhasasilan sekolah dalam mendidik siswa. Ujian nasional dan rapor yang diterima setiap akhir masa belajar akan terlihat indikator keberhasilan siswa, sehingga kognitif menjadi aspek yang ditekankan di sekolah.

Kodrat alam merupakan dasar dalam melaksanakan sistem among disamping kemerdekaan. Kodrat alam merupakan faktor yang telah digariskan ada pada pada diri anak. Kodrat alam berupa bakat dan kemampuan siswa. Kodrat alam pada sistem among memuat pengembangan bakat dan minat siswa yang diberikan dalam bentuk kegiatan ekstrakurikuler di sekolah. Diantara ekstra yang diadakan adalah karawitan, seni bela diri, drum band, dan seni tari.

Setiap siswa memiliki potensi yang berbeda-beda, baik secara kognitif, bakat, dan minat. Dalam rangka mendukung potensi peserta didik yang berbeda-beda sekolah memberikan program tambahan untuk mengembangkan potensi mereka. Dalam rangka melaksanakan program tersebut, salah satunya sekolah menyediakan program kesenian daerah yang terbagi menjadi TIK, seni tari, karawitan, dan Drum band. Pelajaran seni tari dimasukkan dalam kegiatan Intra sekolah, untuk kemudian anak-anak yang memiliki minat dan bakat dibidang tari.

Keteladanan merupakan cara dalam melaksankaan sistem among. Keteladan pamong memungkinkan siswa untuk meniru atau melakukan tindakan serupa yang diharapkan dapat dilakukan oleh siswa. Tindakan tersebut memuat tindakan budi pekerti. Keteladanan tersebut secara spontanitas dan sadar memberikan keteladan pada siswa.

Pembiasaan dilakukan pamong di sekolah selain keteladanan. Pembiasaan yang dilakukan pamong dilakukan di kelas maupun di luar kelas. Berbagai pembiasaan tersebut dilakukan agar siswa berperilaku seperti yang diharapakan, utamanya adalah budi pekerti. Contoh pembiasaan tersebut adalah pamong datang awal setiap pagi menunnggu siswa di depan gerbang sekolah untuk menyambut siswa. Hal tersebut berguna untuk membiasakan kedisiplinan dan sopan santun pada pamong.

Pembelajaran atau pengajaran merupakan salah satu upaya dalam mencapai tuju- 
an pendidikan di SD. Pembelajaran tersebut harus memenuhi tujuan seperti dalam pendidikan Ki Hadjar Dewantara yaitu mengembangkan pribadi siswa, menjadi anggota masyarakat dan memperoleh masa depan. Sistem pembelajaran yang dilaksanan di SD Taman Muda oleh pamong dilaksanakan mengggunakan sistem dinas pendidikan dari dinas.

Pelaksanaan pembelajaran dilaksanakan dengan sistem pamong mata pelajaran mulai dari kelas tiga hingga kelas enam terintegrasi budi pekerti dan budaya untuk setiap mata pelajaran. Pamong mengajar siswa dengan sistem mata pelajaran melakukan integrasi budi pekerti oleh setiap pamong dalam kegiatan pembelajaran.

Pemberian hukuman diberikan selaras dengan perbuatan siswa. Meminta maaf merupakan pertanggung jawaban siswa atas kesalahan yang diperbuatnya. Disamping itu, pemanggilan terhadap orang tua merupakan bentuk kerja sama orang tua dan pihak sekolah pada anak didik. Hukuman diberikan pamong ketika siswa melanggar etika, aturan, dan perintah. Hukuman yang dilaksanakan bervariasi sesuai dengan kebijakan dari pamong dan bentuk kesalahan siswa.

SD Taman Muda Jetis merupakan satu diantara dua sekolah Tamansiswa yang menjalankan konsep Ki Hadjar Dewantara. Mempertahankan konsep dalam arus perubahan merupakan hal yang sulit. Banyak kendala yang dihadapi dalam memertahankan konsep Ki Hadjar Dewantara dalam konsep di sekolah. Implementasi konsep pendidikan Ki Hadjar Dewantara membutuhkan kerja keras di Sekolah Dasar.

Berbagai kendala dalam mengiplementasikan konsep dari Ki Hadjar Dewantara, pertama adalah fasilitas. Kekurangn fasilitas tersebut berupa jumlah dan luas ruangan. Jumlah ruangan dapat minim untuk meningkatkan minat dan bakat. Ruangan dapat dikatakan sempit untuk meningkatkan kebebasan dan sifat aktif siswa. Halaman sekolah juga kurang mendukung sebagai tempat bermain siswa, meskipun terdapat tempat bermain dari siswa taman kanak-kanak yang bisa digunakan siswa SD untuk bermain. Kurang-nya fasilitas, sebagai salah satu penghambat dalam mengimplementasikan konsep

Kedua, pemahaman pamong mengenai konsep pendidikan Ki Hadjar Dewantara yang kurang mendalam Kurangnya pema- haman pamong juga dilihat dari pelaksanaan proses mendidik siswa, yang dalam beberapa hal memiliki ketidaksesuain dengan konsep Ki Hadjar Dewantara. Ketiga, Kurangnya peningkatan kualitas pamong dari yayasan Tamansiswa. Peningkatan tersebut seperti seperti workshop, diskusi, dan pelatihan dari Tamansiswa yang sangat kurang. Pelatihan atau workshop yang diadakan oleh yayasan dilakukan selama satu tahun sekali. Keempat, terdapat pamong yang tidak volunteer. Pamong yang tidak volunteer tersebut cenderung pada karakter yang timbul pada diri pamong.

\section{Modal sosial dalam konsep pendidikan Ki Hadjar Dewantara}

Modal sosial merupakan modal dalam suatu hubungan antarindividu yang terbentuk karena adanya rasa saling percaya antarindividu, kerja sama, dan jaringan yang ada pada hubungan tersebut. Definisi modal sosial dalam persepsi kebanyakan pamong di SD Taman Muda Jetis tidaklah demikian. Modal sosial menurut pamong di SD Taman Muda merupakan bekal yang diberikan kepada siswa untuk memberikan bekal hidup bermasyarakat. Bekal tersebut berupa tata cara dalam bergaul dan berinteraksi yang diaajarkan dan dibimbing oleh pamong di sekolah.

Modal sosial merupakan interakasi yang terjalin dalam hubungan antarindividu. Modal sosial memberikan kekuatan karena adanya rasa saling percaya yang terjalin, kerja sama antarindividu atau kelompok dan jaringan. Konsep Pendidikan Ki Hadjar Dewantara, yang dilaksanakan di SD Taman Muda Jetis tetap eksis dan ada karena adanya modal sosial yang terjalin di sekolah.

Trust atau rasa saling percaya terbangun dalam rangka mencapai tujuan pendidikan tingkat satuan, dalam hal ini rasa saling percaya di sekolah yang berperan dalam mencapai tujuan tersebut. Dengan rumusan dan target sekolah seperti yang tercantum dalam visi-misi, mengaruskan pamong memiliki rasa saling percaya yang terhubung antarindividu dan instansi.

Rasa saling percarya tersebut dilakukan oleh kepala sekolah, pamong, dan karyawan di sekolah. Kekeluargaaan menjadi kunci dalam trust yang terbangun di SD Taman Muda Jetis. Kekeluargaan merupakan perasaan yang menganggap orang lain seperti halnya keluarga sendiri. Rasa saling percaya akan 
muncul dari individu untuk membentuk rasa percaya pada orang lain.

Jaringan merupakan ikatan antarindividu yang terbentuk antarindividu maupun dalam komunitas atau kelompok. Jaringan dapat dikatakan bentuk hubungan timbal balik dalam suatu kelompok. Dalam lingkungan sekolah timbal balik tersebut untuk memenuhi tujuan dan kebutuhan dalam dunia pendidikan itu sendiri. Di SD Taman Muda Jetis, jaringan yang dimaksudkan keterkaikan antarindividu serta kelompok yang berguna dalam mencapai tujuan sekolah yang didasarkan pada konsep pendidikan Ki Hadjar Dewantara. Temuan lapangan memberikan gambaran bahwa pamong, kepala sekolah, karyawan, dan orang tua saling terkait. Keterkaitan tersebut dalam mewujudkan tujuan pendidikan, sistem pamong, dan tut wuri handayani.

Implementasi konsep Ki Hadjar Dewantara, rasa kekeluargaan di SD Taman Muda Jetis membentuk jaringan kuat antarpamong, yang dibuktikan dengan merasa ikut bertanggung jawab pada kelas lain. Keterkaitan tersebut saling melengkapi antarpamong yang menjadikan proses pendidikan berjalan dengan lancar.

Keterkaitan antarpamong terjadi antarkelas terlebih pada kelas 3 hingga 6 . Hal tersebut terjadi lantaran sekolah Taman Muda menggunakan sistem among mata pelajaran (mapel). Pamong saling terhubung dalam rangka memantau kemajuan siswa dalam pembelajaran. Dalam hubungannya dengan konsep pendidikan Ki Hadjar Dewantara, keterkaitan antarpamong terhubung karena adanya instansi yang memberikan keterikatan antarpamong.

Kerja sama dilaksanakan dalam berbagai berbagai khususnya dalam melaksanakan konsep yang diwariskan. Kerja sama di sekolah dilakukan oleh kepala sekolah, pamong, yayasan, dan orang tua siswa. Kerja sama tersebut meliputi membangun jalannya pelaksanaan tujuan pendidikan, sistem among, serta tut wuri handayani. Kerja sama yang terbangun di internal sekolah terlihat dalam mengiplementasikan pelaksanaan kurikulum dan pembelajaran, pengadminstrasian, berbagai kegiatan dan event sekolah serta diluar sekolah. Pengelolaan sekolah dilakukan secara bersama-sama karena adanya kekeluargaan. Kekeluargaan menjadi inti dalam jaringan kuat di sekolah.
Norm atau Norma merupakan bentuk aturan yang disepakati bersama dalam mengatur dan memenuhi kebutuhan dalam kelompok. Pada pelaksanaan pendidikan tingkat satuan, norm tersebut berupa pranata dalam rangka mencapai tujuan tingkat satuan tersebut. Norm yang ada berupa bentuk aturan dalam rangka mencapai tujuan dari konsep $\mathrm{Ki}$ Hadjar Dewantara.

Bentuk norm yang ada di SD Taman Muda Jetis sendiri adalah nilai-nilai dan budaya dari masyarakat dalam melaksanakan konsep pendidikan Ki Hajar Dewantara. Kekekeluargaan merupakan norma dalam konsep yang diimplementasikan oleh pamong. Disamping hal tersebut, tuntutan sebagai seorang pendidik menjadi norm yang mengikat para pamong. Dalam berhubungan dengan orang tua juga tidak menggunakan norm tertentu. Kekeluargaan merupakan norm dalam pelaksanan konsep Ki Hadjar Dewanta. Aturan atau pranata yang memaksa dan mengikat serta memiliki sanksi tidak terdapat di sekolah. Hal tersebut didapat dari pernyataan pamong dan ketua yayasan Taman Siswa cabang Jetis.

\section{Pembahasan}

Ki Hadjar memberikan maksud dan tujuan pendidikan bukan hanya pada pengetahuan yang ditekankan padai aspek kognitif. Pendidikan harus senantiasa memberikan keseimbangan akal dan budi. Di samping itu, bekal hidup bermasyarakat juga perlu diberikan, seperti ketermpilann sosial, bekal keagamaan, dan budaya. Ditambah lagi persiapan masa depan anak perlu dibekali dengan keterampilan-ketampilan yang dapat mendukung untuk bertahan hidup, dan mencapai kebahagiaan lahir serta batin (Dewantara, 2011, p. 20). tujuan tersebut secara implisit terimplementasi di SD taman Muda dalam visi dan misi serta dilaksanakan dalam program kurikurum sekolah.

Among method atau Sistem among merupakan metode yang digunakan dalam mendidik siswa di Tamansiswa. Sistem among dilaksanakan layaknya pamong berperan sebagai pengasuh dari anak, momong, among dan ngemong. Pamong, sebagai seorang pamong yang berperan menempatkan siswa sebagai subjek dalam pendidikan.

Tujuan dari penggunaan sistem among adalah agar anak merdeka dan tidak "diper- 
kosa" lahir dan batinnya. Anak diberikan kemerdekaan lahir dan batin agar dapat tumbuh sesuai dengan kodrat yang dimiliki anak. Pelaksannaan sistem among dilaksanakan dilaksankan di SD dengan beberapa cara, yaitu, (a) menjadi contoh; (b) pembiasaan; (c) pengajaran; (d) perintah, paksaan, dan hukuman (Samho, 2013, p. 79).

Kerata basa pamong, digugu lan ditiru menjadi salah satu metode mendidik budi pekerti anak. Keteladanan merupakan tindakan yang dilakukan agar siswa dapat meniru dan melakukan yang diperbuat oleh pamong. Pelaksanan keteladanan dilakukan pamong di sekolah dengan perilaku yang dapat dicontohkan pada siswa.

Pelaksanaan sistem among juga dilakukan dengan pembiasaan.Pembiasaan membentuk perilaku, watak atau karakter anak. Pembisaaan tersebut dilaksanakan berdasarkan aturan sekolah, aturan kelas dan lebih dalam lagi dilaksanakan dengan mengacu pada norma agama dan nilai budaya yang berkembang dalam masyarakat jawa, seperti menghormati yang lebih tua dengan bertutur kata sopan sesuai dengan unggah ungguh. Hal tersebut sesuai dengan pepatah jawa ajinning diri gumantung ing lathi, yang artinya bahwa kehormatatan seseorang berada pada tutur katanya (Purwadi, 2007, p. 96). Pelaksanaan pembiasaan mengenai nilai-nilai budaya diantaranya dilakukan dengan memberi wejangan. Bahasa daerah, yaitu bahasa jawa disamping menggunakan bahasa Indonesia.

Pembiasaan dilaksanakan secara konsisten, agar anak juga malaksanakan perbuatan karena terbisa yang berujung pada suatu budaya yang baik. Pembiasaan merupakan kegiatan yang dilakukan secara terus-menerus dan ada dalam kehidupan sehari-hari anak sehingga menjadi kebiasaan yang baik, yang meliputi aspek perkembangan moral dan nilainilai agama, serta pengembangan sosial, emosional dan kemandirian (Poerwanti, 2013, p. 40).

Pengajaran diberikan untuk memberikan bekal kognitif pada anak. Pengajaran merupakan bentuk pemerdekaan lahiriah (Dewantara, 2011, p. 4). Pengajaran di sekolah tidak hanya mengajarkan pengatahuan dan kepandaian. Terdapat muatan budi pekerti yang ditamankan pada siswa. Budi pekerti dilakukan secara spontan pada siswa dalam pengajaran yang dilakukan, melalui pembiasa- an dan diberikan pengertian. Pengertian diberikan pada anak agar menyadari apa yang dilakukan.

Salah satu tujuan dari pengajaran adalah untuk memberikan pengertian dan makna dari tindakan yang dilakukan oleh anak. Kesadaran akan membentuk anak untuk melakukan tindakan secara sadar atas tindakan yang dilakukan, termasuk konsekuensinya. Harapannya akan lahir manusia yang sadar akan diri dan keberadaannya, bukan menjadi robot yang terkurung dalam tubuh manusia yang tidak memahami ngerti, ngrasa, dan nglakoni.

Terakhir adalah hukuman, paksaan dan perintah yang diberikan oleh sebagai bentuk konsekuensi yang diberikan dalam memberikan pengertian dan memahamkan anak akan setiap tindakan yang dilakukan. Dewantara $(2011$, p. 400) menerangkan bahwa hukuman merupakan instrumen yang digunakan dalam menanamkan anak bahwa setiap tindakan memiliki konsekuensi terhadap diri sendiri dan orang lain yang harus dipertanggungjawabkan ketika melanggar aturan, norma, dan budi pekerti yang diberlakukan dalam masyarakat. Disamping itu, hukuman dan paksaan berguna untuk menanamkan rasa keadilan bagi anak.

Sistem among merupakan metode yang digunakan dalam medidik yang memberikan kasih sayang, momong, among dan ngemong. Pelaksanaan sistem among dalam pendidikan di Tamansiswa dilakaukan dengan empat cara. Cara-cara tersebut adalah keteladanan, pembiasaan pengajaran dan hukuman. Cara-cara tersebut merupakan agar pendidikan dapat menjadi tempat berkembangnya siswa yang dapat ngerti, ngrasa dan nglakoni.

Tut wuri handayani merupakan bagian tak terpisahkan dari sistem among. Tut wuri handayani merupakan slogan dari $\mathrm{Ki}$ Hadjar Dewantara yang berarti dibelakang memberikan dorongan. Dewantara (2011, p. 59) menjelaskan bahwa tut wuri handayani merupakan pemimpin-pemimpin siswa yang berada di belakang sebagai penasehat dan pemberi dorongan.

Implementasi konsep pendidikan $\mathrm{Ki}$ Hadjar Dewantara di SD Taman Muda Jetis berprinsip pada kemerdekaan. Merdeka merupakan wujud kemampuan manusia untuk hidup dengan kekuatan sendiri. Dewantara (2011, p. 3) mengartikan manusia merdeka merupakan manusia hidupnya tidak tergan- 
tung pada orang lain, baik itu lahir maupun dan hidup atas kekuatan sendiri. Kemerdekaan tersebut tercermin dari kebebasan yang diberikan pada siswa pada siswa. Kemerdekaan pada pada konsep pendidikan Ki Hadjar Dewantara merupakan kemerdekaan yang memberikan kebebasan yang memiliki konsekuensi. Konsekuensi tersebut diperoleh oleh anak atas praksis yang dilakaukan. Kemerdekaan tersebut berarti memberikan pendidikan pada anak untuk senantiasa bertanggung jawab atas pilihan-pilihan yang dibuatnya.

Kemerdekaan atau kebebasan tersebut bukanlah bebas sebebas-bebasnya, namun bebas yang terbatasi pada aturan dan norma. Pamong memberikan teguran dan nasehat pada anak. Dewantara (2011, p. 372) menjelaskan mengenai kemerdekaan tidak lepas dari kodrat manusia sebagai bagaian dari liangkungan sosial.

Kodrat alam merupakan prinsip yang meleka dalam konsep Pendidikan Ki Hadjar Dewantara. Kodrat alam merupakan bentuk penghargaan proses pendidikan yang memberikan kemerdekaan dan tidak melupakan bahwa siswa hanya manusia biasa yang sedang tumbuh dan berkembang. Kodrat tersebut juga bermakna bahwa anak sebagai subjek dalam pendidikan, merupakan bagian dari alam tempat anak tinggal. Tuntunan orang dewasa dibutuhkan dalam membimbing dan mengarahkan anak menjadi pribadi yang matang nantinya.

Pendidikan yang berlangsung tidak adalah sebuah tuntunan. Dewantara (2011, p. 21) mengatakan "Pendidikan itu hanya suatu "tuntunan" dalam hidup anak-anak kita. Itu berarti, bahwa hidup tumbuhnya anak-anak terletak diluar kecakapan atau kehendak kaum pendidik".Hal tersebut memberikan isyarat pada pendidik bahwa terdapat zona yang tidak boleh dilalui kaum pendidik untuk membentuk dan mempengaruhi anak diluar kodratnya sebagai anak.

Proses pendidikan di Taman Muda membawa prinsip kodrat alam telah terlaksana. Sebagai contoh adalah pamong yang memberikan memberikan fleksibilitas untuk bermain, bersenda gurau dan bercengkrama dalam kegiatan pembelajaran. Pembelajaran yang fleksibel tersebut tidak lepas dari pemahaman pamong bahwa secara kodrati anak adalah manusia yang sedang berkembang dan tidak dapat diam ditempat dalam waktu yang lama.
Proses pendidikan yang membangun konsep anak merupakan bagian alam disampaikan melalui alat pendidikan. Alat pendidikan yang berupa keteladan, pembiasaan, pengajaran, dan perintah paksaan dan hukuman. Hal paling sederhana yang diberikan adalah mengenai sampah. Pamong memberikan teladan disamping membiasakan anak untuk membuang sampah paad tempatnya. Di kelas, pamong juga memberikan pengtian tersebut secara berulang ulang dalam pengajaran. Disamping itu, perintah, paksaan dan hukuman juga diberikan pamong pada anak untuk membuang sampah pada tempatnya.

Pelaksanaan konsep pendidikan $\mathrm{Ki}$ Hadjar Dewantara tidak serta merta lepas dari kendala. Pertama adalah fasilitas yang tersedia. Fasilitas merupakan hal penting dalam proses pendidikan, meskipun fasilitas bukan segalnya. Montessori (1912, p. 81) mengatakan bahwa asilitas sekolah sebagai sarana belajar dan tempat bermain. Fasilitas menjadi penunjang bagi perkembangan siswa menjadi hal yang penting. Kurangnya fasilitas di sekolah bisa "diakali" dengan adanya lingkungan sebagai fasilitas dan media tak terbatas bagi siswa.

Kedua, pemahaman pamong mengenai konsep pendidikan Ki Hadjar Dewantara yang kurang mendalam. Kurangnya pemahaman tersebut, dikarenakan terdapat pamong yang mengejar bukan sebagai panggilan jiwa. Pamong pelu meningkatkan kualitas agar anak dapat berkembang dengan optimal sesuai dengan kodratnya (Haryadi, 1990, p. 18). Kurangnya penguasaaan dalam konsep pendidikan Ki Hadjar Dewantara tersebut berhubungan dengan poin ketiga yaitu, kuranya pelatihan dari yayasan Tamansiswa. Pelatihan dari yayasan untuk pamong yang kurang dengan hanya dilaksanakan satu tahun sekali. Pelatihan tersebut berguna sebagai peningkatan kualitas pamong dalam mendidik. Disamping pelatihan, pamong juga perlu meningkatkan kualitas kompetensi pendidik. Peningkatan kualitas kompetensi para pamong penting dilakukan dalam rangka mencapai tujuan. Pamong berperan dalam pengembangan petensi siswa, baik itu mengenai minat, bakat, budi pekerti, serta intelektual siswa, dan hal tersebut masih menjadi kendala untuk meningkatkan kualitas dari para pamong.

Terakhir, terlepas dari pemahaman pamong yang masih kurang mengenai konsep 
pendidikan Ki Hadjar Dewantara, namun cara-cara pamong dalam melaksanakan tujuan dan metode dapat dijadikan contoh. Tujuan dan konsep pendidikan Ki Hadjar Dewantara di SD Taman Muda pantas dijadikan contoh karena dapat menciptakan budi pekerti luhur dan memupuk rasa kekeluargaan di sekolah.

\section{Modal sosial (Sosial Capital) dalam Implementasi Konsep Pendidikan Ki Hadjar Dewantara}

Modal sosial merupakan sumber daya dalam mencapai tujuan dengan berdasarkan dalam hubungannya dengan struktur sosial, kelembagaan dan kelompok. Modal sosial memberikan kaitan dan hubungan antarindividu dan perilaku dalam sebuah struktur sosial, kelembagaan dan kelompok. Modal sosial merupakan kekuatan yang dinamis dalam investasi sosial untuk memberikan kemanfaatan dan tujuan.

Di SD Taman Muda Jetis, para pamong mempersepsikan modal sosial sebagai konsep dalam menanamkan keterampilan sosial melalui lembaga sekolah. Definisi dalam persepsi pamong tersebut terjadi karena modal sosial (social capital) belum familiar dikalangan pamong. Modal sosial lebih dikenal sebagai cara dan keterampilan dalam hidup secara sosial dalam masyarakat.

Modal sosial menjadi kekuatan atau daya yang dinamis didasarkan atas dasar rasa saling percara (trust), jaringan, dan norma (Norm). Pada pelaksanaan konsep pendidikan yang didasarkan pada konsep pendidikan $\mathrm{Ki}$ Hadjar Dewantara, kekeluargaan mejadi daya dalam memberikan manfaat kelembagaan. Kekeluargaan tersebut berimplikasi pada rasa saling percaya, jaringan dan norma yang ada di sekolah.

Rasa saling percaya sebagai salah satu sumber daya sosial di SD Taman Muda Jetis yang terjadi antara yayasan cabang, Kepala sekolah, pamong, karyawan dan orang tua siswa. Rasa percaya yang ditunjukkan oleh yayasan dilakukan dengan adanya penyerahan tanggung jawab kepada kepala sekolah. Yayasan memberikan amanah kepada kepala sekolah untuk mengarahkan sekolah menuju apa yang dicita-citakan oleh Ki Hadjar Dewantara.

Kepercayaan juga ditunjukkan oleh kepala sekolah pada pamong. Semua pamong dianggap sama oleh kepala sekolah baik itu merupakan pamong baru maupun pamong yang sudah lama berada di sekolah. Sikap egaliter tersebut dikarenakan nilai dan suasana kekeluargaan yang terjalin di ruang pamong. Hal yang sama juga dilakukan pamong terhadap kepala sekolah. Pamong percaya bahwa kepala sekolah dapat mengarahkan pamong baik baru dan lama untuk mencapai visi sekolah. Kepercayaan juga ditunjukkan dengan sesama pamong. Hal tersebut terjadi sebagai adanya rasa kekeluargaan yang ada di sekolah. Rasa kekeluargaaan tersebut memupuk rasa saling percaya, sepertihalnya rasa kekeluargaan dalam sebuah keluarga primer. Kepercayaan juga terjadi antara orang tua dan sekolah. Rasa percaya orang tua menyekolahkan anaknya terjadi juga karena adanya ikatan dari pendahulu yang menimbulkan kepercayaan. Kedekatan antara orang tua dan pamong yang memperkuat rasa saling percaya.

Jaringan (network) berperan sebagai kapital dalam hubungan sosial, kelembagaan, kelompok dan instansi. Jaringan sekolah, terjadi antara yayasan, sekolah (kepala sekolah, pamong, karyawan) dan orang tua siswa. Sekolah dan yayasan membentuk jaringan berupa pelatihan dan pengawasan dalam pelaksanaan sistem among. Pelatihan tersebut rutin dilakukan,namun hnya satu hingga dua kali dalam satu tahun. Sementara, untuk pengawasan yang dilakukan dari yayasan mengenai implemantasi konsep Ki Hadjar Dewantara belum dilaksanakan secara ideal.

Jaringan antarpamong terbangunn atas kepercayaan diatas dan rasa kekeluargaan. Jaringan terlihat dari kerja sama dan rasa kebersamaan antarpamong.Pada kerja sama antarpamong berlangsung dalam kegiatan pembelajaran dan diluar pembelajaran. Pada kegiatan pembelajaran, ketika terdapat pamong yang tidak mengisi kelas atau anak terlalu bebas tanpa ada pamong yang bertugas, maka pamong secara suka rela dan tanpa perintah, pamong lain datang untuk mengisi kelas tersebut. Pada kegiatan istirahat, pamong juga sering berbagi pengalaman mengajar dalam sehari-hari serta mendiskusikan siswa atau mata pelajaran tertentu. Gotong-royong dalam mendidik siswa merupakan wujud dari rasa keluarga. Dewantara (2011,p. 6) mengatakan bahwa rasa keluarga merupakan rasa diri yang berkembang menjadi rasa keluarga timbul karena adanya persamaa kebutuhan dan keadaan, baik lahir maupun batin, eko- 
nomis, kultural, tentang penghidupan dan kehidupan.

Di samping jaringan antarpamong, hubungan yang terjalin dalam jaringan yang terjadi adalah antara para pamong dan orang tua. Jaringan tersebut meliputi komunikasi yang mendekatkan antara pamong dan orang tua siswa. Seperti halnya hubungan antara pamong, orang tua siswa dan pamong memilii ikatan emosi seperti layaknya teman yang tidak canggung bersenda gurau. Berdasarkan hasil penelitian, hal tersbut diakibatkan karena budaya kekeluargaan yang diterapakan di sekolah telah terjadi sejak lama. Hal tersebut diturunkan pada genarasi para pamong berikutnya. Jaringan antara sekolah dan orang tua akan memperkuat kualitas pendidikan dan prestasi siswa dalam pembelejaran.

Di samping kepercayaan dan jaringan norma juga menjadi kekuatan dalam mencapai tujuan instansi. Norma (norm) merupakan pranata yang meberikan batasan, atauran pada suatu komunitas, kelompok sosial dan kelembagaan dalam interaksi sosial. Norma ada sebagai aturan yang mengatur anggotanya dalam sebuah instansi. Aturan tersebut merupakan kesepakatan dalam kelompok tersebut, atau merupakan nilai hasil interaksi yang disepakati baik itu tertulis atau tak tertulis. Dewantara $(2011$, p. 6) mengatakan bahwa rasa yang timbul karena adanya persamaa kebutuhan dan keadaan, baik lahir maupun batin, ekonomis, kultural, tentang penghidupan dan kehidupan menimbulakan aturan, ketertiban dan kedamaian dalam peri kehidupan bersama (percaharian, urusan negeri, bahasa, seni, agama dan pengetahuan). Rasa yang dimaksudkan Ki Hadjar merupakan salah satu bentuk norma dalam interaksi yang berguna sebagai batasan individu sebagai anggota kelembagaan.

Norma dalam implementasi konsep Pendidikan Ki Hadjar Dewantara berupa nilainilai yang ada dalam masyarakat jawa, yaitu kekeluargaan. Nilai tersebut tidak tertulis dalam dokumen sekolah, namun menjadi kesepakatan. Kedekatan antarpamong, terlihat seperti keluarga dalam keluarga primer. Kedekatan tersebut menjadi kekuatan dalam mengimpletasikan konsep Ki Hadjar Dewantara. Rasa ewuh dan pekewuh tidak ditunjukkan pamong dalam interaksi yang dilakukan. Hal tersebut memungkinkan pamong untuk mengoptimalkan daya untuk mencapai tujuan dan manfaat dalam instansi SD Taman Muda Jetis.

Kekeluargaan menjadi daya dan kekuatan dalam melaksakan konsep dari Ki Hadjar Dewantara. Salah satu implikasi dari kekeluargaan adalah gotong royong sebagai pranata sekolah. Gotong royong merupakan wariwan budaya jawa yang dinilai sebagai pranata penting dalam memecahkan berbagai persoalan komunitas. Gotong royong menandakan kuatnya nilai-nilai kebersamaan atau kooperasi serta solidaritas kelompok. Rasa keluarga inilah yang menjadi kekuatan untuk melaksanakan konsep pendidikan Ki Hadjar Dewantara.

Sanksi yang diberlakukan di SD Taman Muda Jetis berupa teguran serta dialog. Ketua cabang Tamansiswa Jetis mengatakan bahwa berbagai aturan, atau kedisiplinan hanya akan memberikan batasan pada kemerdekaan, termasuk para pamong. Ketika terdapat norma yang dilanggar, maka sanksi yang diperoleh berupa cara-cara kekeluargaan dalam menyelesaikan masalah atas pelanggaran tersebut serta sanksi sosial yang menjadi akibat akhir.

Kekeluargaan, merupakan modal sosial di SD Taman Muda Jetis. Kekeluargaan menjadikan kebersamaan, dan kedekatan para pamong untuk saling percaya, bekerja sama dan memiliki jaringan dalam menjalankan visi dan misi sekolah. Kekeluargaan yang dimiliki sekolah menjadikan kekuatan dalam mencapai visi dan misi sekolah. Manfaat akan diperoleh dengan menguatnya modal sosial adalah semakin kuatnya potensi pencapain yang diharapakan.

\section{SIMPULAN}

\section{Simpulan}

Konsep pemikiran Ki Hadjar Dewantara mengenai tujuan pendidik, metode pendidikan terimplementasi di SD Taman Muda Jetis. Pelaksanaan konsep pemikiran Ki Hajar Dewantara dalam tujuan pendidikan di Taman Muda dilaksanakan berdasarkan konsep pendidikan Ki Hadjar Dewantara yang diturunkan dalam visi dan misi sekolah. Pamong memberikan berbagai persepsi yang berbeda-beda dalam konsep pendidikan $\mathrm{Ki}$ Hadjar Dewantara. Persepsi yang berbedabeda berdasarkan pemahaman para pamong 
sendiri. Meskipun begitu, tujuan pendidikan tetap selaras dengan konsep Ki Hadjar Dewantara karena visi dan menjadi "rel" dalam pelaksanaan program sekolah.

Sistem among dilakukan prinsip prinsip yang memerdekakan siswa dan menghargai kodrat alam. Meskipun begitu, terdapat kendala-kendala yang tidak serta-merta dapat dijalankan dengan ideal dan sempurna. Kendala-kendala tersebut adalah pemahaman pamong mengenai konsep pendidikan Ki Hadjar Dewanatara, pembelajaran yang kurang kreatif, serta fasilitas yang belum mendukung.

Kekeluargaan, menjadi modal sosial dalam proses pelaksanaan konsep pendidikan Ki Hadjar Dewantara di SD Taman Muda Jetis. Rasa kekeluargaan tersebut didapat dari rasa saling percaya, jaringam, kerja sama, dan norma serta pranata yang berada di SD Taman Muda Jetis. Peran modal sosial pengimplementasian konsep pemikiran Ki Hadjar Dewantara diantaranya adalah trust. Trust berkembang di sekolah di sekolah, dalam bentuk kepercayaan kepala sekolah pada pamong untuk mendidik siswa. disamping itu, sikap egaliter ditunjukkan pada pamong dan karyawan dalam memimpin sekolah dalam mencapai tujuan. Adanya kedekatan kepala warga sekolah juga manunjukkan kepercayaan didalamnya di sekolah. Hubungan baik dan rasa saling percaya antara pihak sekolah dan orang tua juga menjadi bentuk kepercayaan di sekolah.

Network (Jaringan) di sekolah di sekolah berkembang sebagai modal (capital) dalam mendukung konsep pemikiran $\mathrm{Ki}$ Hadjar Dewantara. Jaringan tersebut terjadi dalam tanggunga jawab bersama dalam mendidik anak yang tidak terbatas pada pamong wali. Para pamong melakukan gotong royong dalam mendisik siswa mapun dalam pekerjaan administrasi pengajaran. Disamping itu, peran pamong sebagai pamong mata pelajaran membuat antarpamong terhubung satu sama. Orang tua juga memberikan dukungan dan bantuan terhada program program yang dilaksankan sekolah.

Norm di sekolah dilaksanakan menggunakan sesanti, semboyan dan wejangan dari Ki Hajar Dewantara. Disamping itu, nilai budaya dalam etika, perilaku dan sopan santun menjadi norma yang diterapkan di sekolah. Meskipun warga sekolah merasa sepserti keluarga karena kedekatannya, namun tetap memperhatikan nilai, aturan dan norma dalam berinteraksi dengan orang lain. Norma serta pranata yang dijalankan merupakan bentuk hukum keluarga yang kompromis dengan sanksi sosial sebagai akibat jika terdapat pelanggaran norma dan pranata dalam instansi yang kemudian diserahkan dengan rasa keluarga pada yayasan.

\section{Saran}

Berdasarkan kesimpulan tersebut, diajukan saran sebagai berikut: (1) mengoptimalkan lingkungan sosial dan budaya Yogyakarta untuk menutupi kekurangan fasilitas sekolah; (2) perlunya peningkatan kualitas dan meningkatkan pemahaman para pamong dalam konsep pendidikan Ki Hadjar Dewantara seperti memberikan pelatihan, dan meningkatkan kerja sama dengan Sarjanawiyata; (3) meningkatkan Network (jaringan) sebagai modal untuk meningkatkan kualitas pendidikan di SD Taman Muda Jetis. Jaringan tersebut berupa interaksi yang kuat antara sekolah, orang tua, siswa, dan yayasan yang menaungi sekolah. Jaringan tersebut Sekolah dapat menjadi kekuatan dalam mencapai pendidikan yang diharapkan.

\section{DAFTAR PUSTAKA}

Acar, E. (2011). Effects of social capital on academic success: A narrative synthesis. Educational Research and Reviews, 6(6), 456-461. Retrieved from http://www.academicjournals.org/journal /ERR/article-abstract/8BD71B95320

Coleman, S. J. (1988). Social capital in the creation of human capital. Am. J. Sociol, 94, 95-120.

Darmayanti, S. E., \& Wibowo, U. B. (2014). Evaluasi program pendidikan karakter di sekolah dasar kabupaten Kulon Progo. Jurnal Prima Edukasia, 2(2), 223-234. Retrieved from https://journal.uny.ac.id/index.php/jpe/ar ticle/view/2721/2271

Dewantara, K. H. (2011). Bagian pertama: pendidikan. Yogyakarta: Majelis Luhur Persatuan Tamansiswa.

Field, J. (2005). Social capital and lifelong learning. Great Britain: The Policy Press. 
Haryadi, K. (1990). Modernisasi perguruan tamaniswa: makalah penunjang bagian pendidikan majlis luhur. Palembang: Konferensi persatuan Tamaniswa.

Häuberer, J. (2011). Social Capital Theory. Wiesbaden: VS Verlag für Sozialwissenschaften. https://doi.org/10.1007/978-3-53192646-9

Montessori, M. (1912). The Montessori method; scientific pedagogy as applied to child education in the children's houses with additions and revisions by the author. New York: Frederick A. Stokes Company.

Poerwanti, E. (2013). Sistem indikator nilainilai moral universal sebagai evaluasi reflektif pendidikan karakter di TK. Jurnal Prima Edukasia, 1(1), 30. https://doi.org/10.21831/jpe.v1i1.2314

Purwadi. (2007). Filsafat jawa: Refleksi kebijaksanaan hidup untuk mencapai kesempurnaan lahir batin. Yogyakarta: Cipta Pustaka.

Samho, B. (2013). Visi pendidikan Ki Hajar Dewantara tantangan dan relevansi.
Yogyakarta: Kanisius.

Tobias, J., Wales, J., Syamsulhakim, E., \& Suharti. (2013). Towards better education quality Indonesia's promising path. London: Overseas Development Institute. Retrieved from https://www.odi.org/sites/odi.org.uk/files /odi-assets/publications-opinionfiles/9065.pdf

Wibowo. (2007). Menumbuh kembangkan modal sosial dalam pengembangan partisipasi masyarakat. Jurnal Gagasan M'Power, 5(5).

Wuryadi, K. (2010). Pendidikan karakter bangsa dalam konsep Kebudayaan Ki Hadjar Dewantara. Yogyakarta: Trah Hudyono kerjasama denga perpustakaan Pakualaman.

Yamin, M. (2009). Menggugat pendidikan Indonesia: Belajar dari Paulo Freire dan Ki Hadjar Dewantara. Yogyakarta: Ar-Ruzz Media.

Yusuf, S. (2001). Psikologi perkembangan. Bandung: Penerbit PT. Remaja Rosdakarya. Bandung: PT. Remaja Rosdakarya. 